\title{
Military Training Areas as Semicommons: The Territorial Valorization of Quirra (Sardinia) from Easements to Ecosystem Services ${ }^{+}$
}

\author{
Ginevra Balletto ${ }^{1}\left(\mathbb{D}\right.$, Alessandra Milesi ${ }^{1}$, Nicolò Fenu ${ }^{1}$, Giuseppe Borruso ${ }^{2, *(\mathbb{D})}$ and \\ Luigi Mundula ${ }^{1}$
}

1 Department of Civil and Environmental Engineering and Architecture, University of Cagliari (DICAAR), 09123 Cagliari, Italy; balletto@unica.it (G.B.); alessandra.milesi@gmail.com (A.M.); nicolofenu@gmail.com (N.F.); luigimundula@unica.it (L.M.)

2 Department of Economics, Business, Mathematics and Statistics “Bruno de Finetti" (DEAMS), Trieste University, 34127 Trieste, Italy

* Correspondence: giuseppe.borruso@deams.units.it; Tel.: +39-040-558-7008

+ This article is part of the work of drafting the Municipal Urban Plan of Villaputzu (MUPV) and in the related coastal use plan (LCP) and strategic environmental assessment (SEA): Scientific coordinator Ginevra Balletto. Participated in: MUPV, LCP, and SEA Alessandra Milesi and LCP Nicolò Fenu.

Received: 24 October 2019; Accepted: 8 January 2020; Published: 15 January 2020

\begin{abstract}
The paper addresses the issue of the concurrent use of coastal areas for military training and civil activities, namely tourism. In the paper, starting from the consideration of publicly owned assets as 'semi-commons', we propose a method based on the comparison of planning instruments related to the different uses, and try to model them in a grid, where different weights and degrees of evaluation can be considered, in order to promote, rather than blocking, possible activities, compatible with concurrent use. The military areas in Sardinia (region and island, Italy) are around $234 \mathrm{~km}^{2}$, which constitutes $60 \%$ of the national surface affected by military easements. This situation is due to its geographic position, considered centrality in the Mediterranean for strategic reasons. This contribution evaluates the performance of the Local Coastline Plan (LCP) and the Site management plan of Community Interest (SCI) in conditions of military constraint. The case study is the municipality of Villaputzu South Sardinia, Italy), where an important coastal military easement and the use of the coast for recreational tourism purposes coexist together through specific planning, a consequence of institutional agreements between the Municipal Administration of Villaputzu and the Ministry of Defense. The idea is considering the concurrent possible land uses guaranteed by the different planning instruments, instead of focusing, as it is generally the rule, on the sum of constraints provided by the laws. The local coastline plan has been identified as the ideal planning tool, which addresses the co-existence of apparently opposite land uses and interests, as those expressed by the local municipal planning and those expressed by the military. An evaluation of the congruence of the specific objectives of the LCP and SCI shows how their combined action favors the environmental enhancement of Sardinia, contributing to the formation of ecosystem services, even in particular conditions arising from military easements. These are sites that evolve from 'anticommons' to 'semicommons'. In fact, the military release process in Sardinia, together with the promiscuous military and civil use, activates unique governance policies of their kind that find a significant field of application in Sardinia to guarantee sustainable renewal of economic development of the 'semi-commons' awaiting to become 'commons'.
\end{abstract}

Keywords: landscape connectivity; Natura 2000 network; strategic environmental assessment; protected areas and spatial planning; semi-commons; ecosystem services 


\section{Introduction}

State property indicates a set of publicly owned assets very different from each other. The state property 'Demanio' (as in the Italian Civil Law, art. 822 and following) consists, among others, of the maritime and water state properties (all water bodies and part of lands touched by water), military property (land and ad hoc infrastructure for national defense) and 'accidental' state property (transport infrastructure, cultural buildings and sites). It finally consists of the other assets that are by law subject to the regime proper to the public domain. Such assets can also belong to the regions, metropolitan cities, provinces, or municipalities-the intermediate administrative partitions in Italian system - equally subject to the state property regime. Public use is exercised on state property [1], i.e., the community can enjoy its benefits directly, as in the case of beaches or museums [2], or indirectly, in the case of ports or airports. The main characteristic of these goods is their inalienability, as they can neither be sold - except by a specific new law-nor can they be subject to rights in favor of third parties, except in the ways and limits established by the laws concerning them (Nav. Code 30 et seq.). They always remain state owned even if abandoned for a long time. Among the assets owned by the public, those relating to military uses also take on particular importance in relation to the fact that military defense is configured, in strictly economic terms, as a pure public good-non rival and non-excludable - and therefore, as an asset, the benefits of which fall indistinctly on the totality of the population, a fact that partly explains the huge amount of financial resources that the various states allocate [3]. After a descending phase in the 1990s, starting from 2000, military spending has in fact been continuously growing.

More specifically as in Figure 1, in 2018, the United States of America was the leading country in military spending of the sector, with 649 billion dollars - worth $36 \%$ of the world military spending and 3.2\% of its Gross Domestic Product (GDP), followed by China with 250 billion dollars- $14 \%$ of the world military spending and $1.9 \%$ of its GDP.

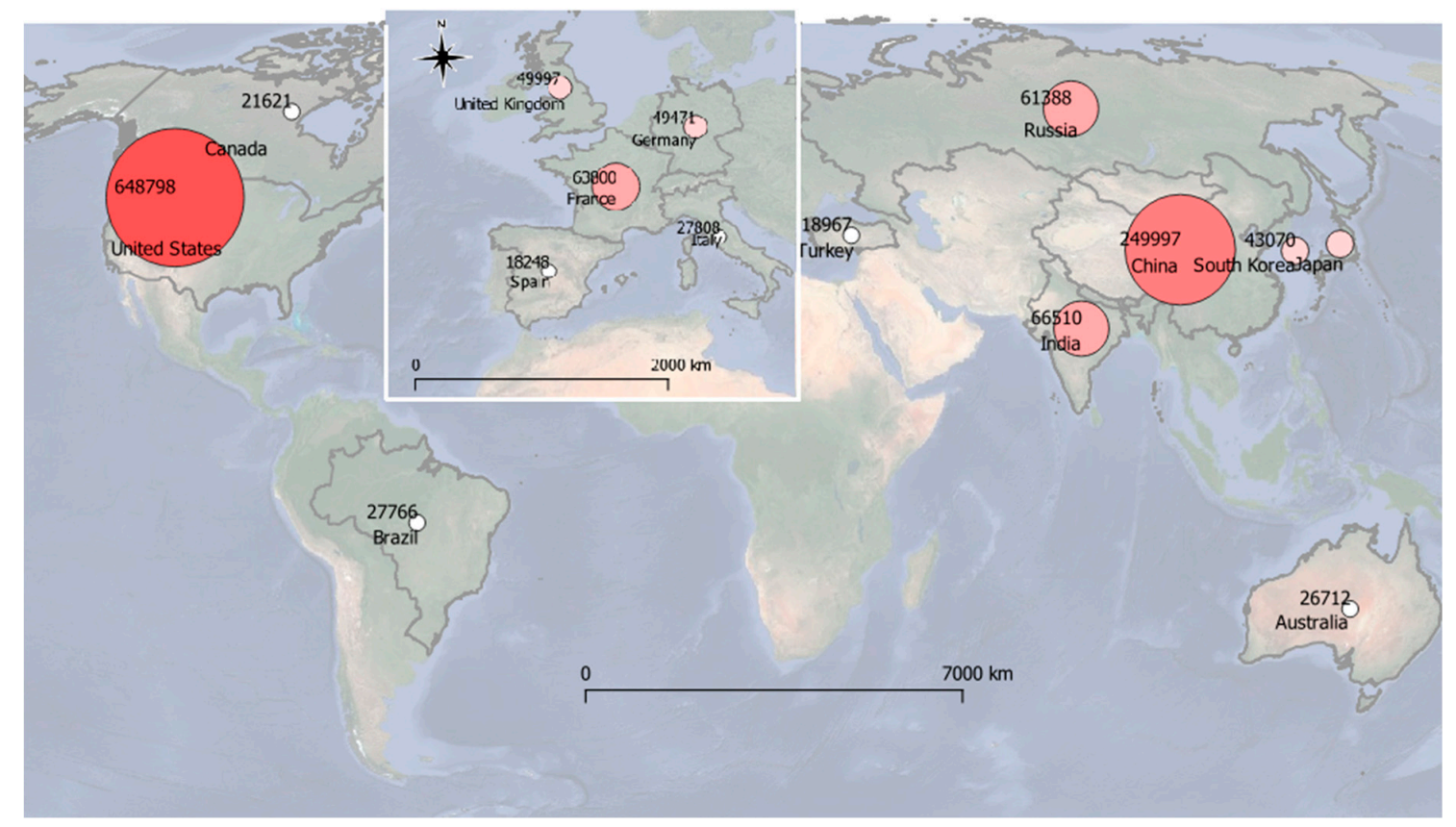

Figure 1. World military expenditure, by region, 1988-2018 (Source: Sipri, 2019. Available online: https://www.sipri.org/research/armament-and-disarmament/arms-transfers-and-militaryspending/military-expenditure).

In this ranking, Italy occupies 11th place, with 27.8 billion dollars (equal to $1.5 \%$ of the World spending and $1.3 \%$ of its GDP). The state properties, on the one hand, can be traced back to the so-called 'enclaves', which are closed areas defined by administrative or cultural characteristics different from 
the surrounding territory and on the other hand, they have characteristics typical of the so-called 'anticommons', first introduced by Michelman in 1982, in contrast to that well-known common [4,5]. This concept was then widely developed by Heller [6] and Eisenberg through the theory concerning the under-use of a resource caused by the right of ownership, and therefore of exclusion, legitimately attributed to a multitude of subjects. Since it is sufficient for only one of the subjects to exercise their right, it is clear that it is very probable, due to the high transaction times and costs necessary to reach a satisfactory agreement for all, that the fruition of that will, lead to a blocking situation in which 'no one has the actual privilege of use' [7]. This is what happens in a by now recurrent form, in the occasion of the dismissal of the state property, both in the urban areas and in extra-urban ones [8]. This brief summary also includes military proving grounds (MPGs), which have the following European locations as shown in Figure 2, with a total of 284 MPGs, mainly concentrated in the United Kingdom (55), the Netherlands (27), France and Germany (26 in each country), Switzerland (22), Spain (21), Italy and Poland (13 in each country).

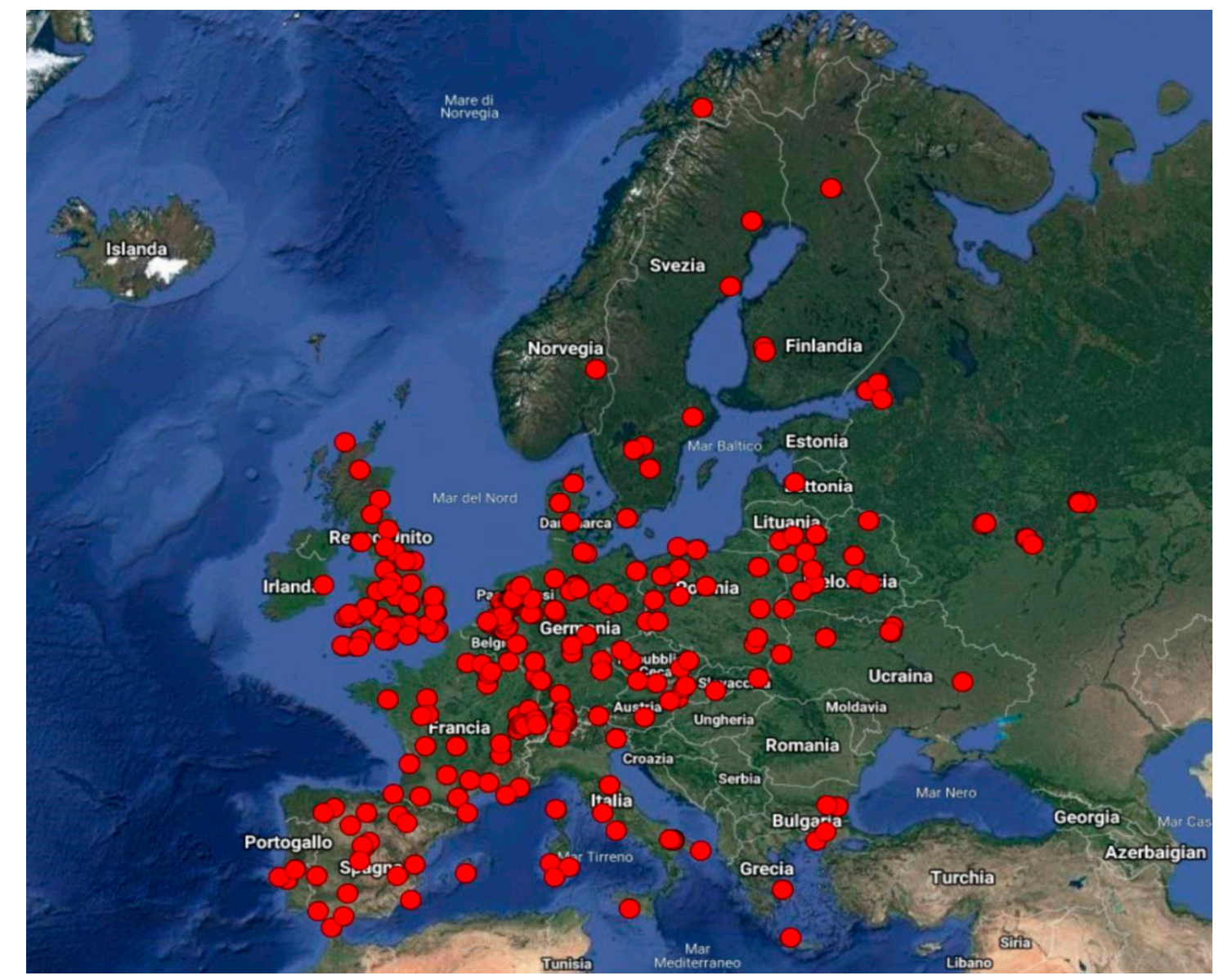

Figure 2. Maps of European military training areas.

The multitude of activities that are carried out there. Activities range from the training of national and foreign units to testing missile prototypes and targets, from quality tests in cooperation with industries and organizations in the aerospace electronics sector and activities related to scientific research, testing, and experimenting of naval ammunition and medium- and long-range terrestrial, including the testing of missile systems, shooting practices, even interforce and for out-of-area operations. They have a significant negative impact $[9,10]$ not only for the territory directly concerned, but also for the local communities, also given by a series of constraints (restriction on flying navigation, bathing, etc.) that they express themselves through easements-According to the Italian Civil Code (art. 1027), an easement (or "praedial servitude" or land easement in the case of land), in the legal 
lexicon, indicates a minor real right of enjoyment over something else, consisting in the weight or limitation imposed on a fund (called servant) for the usefulness of another fund (called dominant) belonging to another person-which vary according to the security that is required.

In particular, military easement involves the set of limitations or prohibitions that can be imposed both on private assets and on public assets located near military installations. The state of servitude can, for example, impose the prohibition of building buildings higher than a given height, and the evacuation of land and housing in conjunction with the operations of exercises-In Italy, military servitude is an institution governed by law n. 898, promulgated December 24, 1976 and subsequent amendments. https://www.normattiva.it/uri-res/N2Ls?urn:nir:stato:legge:1976;898, access 15 September 2019.

If, on the one hand, it is true-as evidenced by several studies [11-16] — that military goods and servitudes perform a substantial function of indirect landscape protection that, in many cases, has prevented or severely limited speculative appetites on territories of great naturalistic value, on the other hand, the intensity and concentration of fire drills, as well as the testing of armaments with the use of fuels and propellants, have a significant impact on the environment and biodiversity [17], whose possible redevelopment may require expensive and difficult land reclamation works. The alleged correlation between military activities and the anomalous appearance of damage to health is still not completely defined. With regard to the economic aspects related to the presence of military bases and Military Proving Grounds (MPG), it should be noted that the territories concerned see potential forms of economic development linked to the exploitation of land for agricultural use and of many sea areas suitable for fishing damaged. To this, it must be added the failure to take off the tourist industry, both due to the unavailability of the sites, and to the interference that military activities have with the normal process of tourist settlement. It is also true, however, that this 'cumbersome' presence is in any case connected to an induced, also industrial, which relies mostly on local labor, as well as the local civilian staff serving in the MPG, which is often local [18].

The problems arising from the presence of military easements are therefore manifold and this feeds the debate on the search for possible solutions. The current orientation of several European countries is aimed at the rebalancing of military easements and the closing down of buildings [19]. In Italy, these procedures have often turned out to be cumbersome and slow due to the frequent regulatory interventions that have repeatedly changed the discipline. Also, in terms of environmental protection, similar considerations apply, in the sense that overcoming the exclusively military destination of certain areas may require guarantees of naturalistic protection [20], especially if such sites are included in the trade-in and exchange agreements program with local authorities. In this framework, the concept of semicommon [21] is well suited to be used for a new interpretation of those areas that present a mixture of civil and military uses in time and space. This concept, in fact, interposed between that of commons and anticommons, establishes an interaction between public and private property [1], and 'allows the right holders to benefit from the joint use of the resource' [22]. The semicommons, in fact, incorporate all private collective rights, but at the same time attribute a series of public rights to other subjects, such as those arising from military servitude. In the presence of this regime, the following two effects arise, deriving from the combined use [22]:

1. Economies of scale are achieved because public and private interests are combined; and

2. Environmental protection - the interaction of private and common use reduces the phenomenon of over-use.

In other words, there is a balance between the right of use and exclusion (Vanneste, Van Hiel, Parisi and Depoorter, 2006; Brede and Boschetti, 2008), typical of semicommons with the following characteristics:

1. A multitude of subjects (public and private) are involved;

2. There is the co-presence of public and private rights; and

3. There is the simultaneous presence of divergent public and private interests. 
To this end, the second section of the contribution, after a brief classification of military easements in Sardinia and the main memoranda of understanding signed over the years between the Ministry of Defense and the Autonomous Region of Sardinia (Section 2.1), is as follows:

1. Classification of the case study 'MPG' of Villaputzu (Section 2.3);

2. Evaluation of coastal planning and management tools (Sections 2.4 and 2.4.1, Sections 2.4.2 and 2.4.3);

3. Assessment of the consistency of the objectives and actions of the coastal planning and management tools (Section 2.4.4).

In the third section, the results are shown and discussed, and finally, in the fourth section, the conclusions and future activities are presented.

\section{Materials and Methods. The Case Study of Villaputzu 'Military Enclave'}

The present contribution analyzes the case study of the coast of the Municipality of Villaputzu in Sardinia, with particular reference to the beach of Murtas, which constitutes the main case of Sardinia in the management and use of the areas subjected to military easements. This easement covers approximately $144.4 \mathrm{~km}^{2}$ and accounts for $62 \%$ of all military easements in Sardinia (Section 2.2). The need to renew the role of military easements in relation to changed geopolitical conditions requires a transition from anticommons to semicommons. In this sense, the proposed approach is that of the transition through ecosystem services within integrated environmental planning. The proposed approach, although to be improved and refined, can be replicated in similar contexts, in coherence with the paradigm underlying ecosystem services.

The case study is interesting as the authors have been involved in the preparation of the local coastline plan (LCP), a compulsory planning tool for municipalities for addressing the issues related to coastal management and planning. Given the peculiarity of the area, being characterized by the important presence of a military proving ground, it was considered as an ideal case study where find possible co-existence features of civilian and military uses could be found.

In particular, the area under study is set up as an enclave within the Military Proving Ground Salto di Quirra (MPGSQ), which has effectively prevented its use by transforming the area into an anticommon. Furthermore, the beach of Murtas is included within a site of community interest (SCI) identified with code ITB040017 and name Stagni di Murtas e S'Acqua Durci. In other words, it is a site where divergent strategic objectives (environmental and military) converge, but which for a long time has been totally prevented from entering. The possibility of making the coastline accessible was reached with the recent state-region agreements (2014-2017), which allowed the use of the coast for tourism purposes in a limited period of the year (1 June-30 September), thus allowing the municipal administration of Villaputzu to equip itself with the appropriate littoral use plan (LCP). The authors, after framing the main state-region and municipality agreements and protocols (Section 2.1), the military easements in Sardinia (Section 2.2), and the analysis of the Villaputzu case study (Section 2.2), proposed the following methodology organized according to the following phases:

- Description of the case study (Section 2.3);

- Evaluation of the LCP and SCI (Sections 2.4.1-2.4.3); and

- Evaluation of the congruence of the specific objectives (qualitative and quantitative) and of the (qualitative) actions of the LCP and SCI (Section 2.4.4)

\subsection{Agreements and Memorandum for the Reorganization of Military Areas in Sardinia}

In Italy, military easements date back to the 1950s and derive from international agreements signed by Italy as a defeated country, at the end of World War II, in particular by the bilateral 'Mutua Sicurezza' (Reciprocal Security) agreement (1952) under which the United States imposed military bases in Italian territory. These agreements provide for the limitation of the right of ownership in 
the areas adjacent to installations of military interest. In 1976, the first law governing all matters of military servitude was issued (L. December 24, 1976, No. 898 `New Regulation of military easements), which provided for the establishment, for each region, of a joint commission with the task of assessing the compatibility of military programs with territorial development plans. With the National Law 104/1990, a list of the regions most affected by military easements was introduced to provide for the provision of compensation with the protocol of an understanding between the Ministry of Defense and ARS of 09.08.1999. Below is the list of the main agreements and memorandum of the Ministry of Defense and ARS as in Table 1.

Table 1. Main agreements and memorandum for the reorganization of military areas in Sardinia.

\begin{tabular}{|c|c|c|}
\hline Date & Document Type & Object \\
\hline 9 August 1999 & $\begin{array}{l}\text { Memorandum of Understanding } \\
\text { between the Ministry of Defense and the } \\
\text { Autonomous Region of Sardinia }\end{array}$ & $\begin{array}{l}\text { Regulation of compensation to economic operators } \\
\text { for the removal of water bodies affected by } \\
\text { military exercises }\end{array}$ \\
\hline $\begin{array}{l}8 \text { September } \\
2005\end{array}$ & $\begin{array}{l}\text { Memorandum of Understanding } \\
\text { between the Ministry of Defense and the } \\
\text { Autonomous Region of Sardinia }\end{array}$ & $\begin{array}{l}\text { Integration of the } 1999 \text { Memorandum of } \\
\text { Understanding with the calculation of additional } \\
\text { compensation due to the economic operators of the } \\
\text { Teulada and Sant'Anna Arresi marinas }\end{array}$ \\
\hline $\begin{array}{l}10 \text { November } \\
2006\end{array}$ & $\begin{array}{l}\text { Agreement between the Ministry of } \\
\text { Defense and the Autonomous } \\
\text { Region of Sardinia }\end{array}$ & Reorganization of the military presence on the island \\
\hline 28 March 2007 & $\begin{array}{l}\text { Memorandum of Understanding } \\
\text { between the Ministry of Defense and the } \\
\text { Autonomous Region of Sardinia }\end{array}$ & $\begin{array}{l}\text { Disposal by the ministry of the buildings listed in the } \\
\text { attached tables and the contextual commitment of the } \\
\text { Region to the relocation of the functions performed } \\
\text { in the buildings for which the disposal will take place }\end{array}$ \\
\hline 7 March 2008 & $\begin{array}{l}\text { Program Agreement between the } \\
\text { Ministry of Defense, the Autonomous } \\
\text { Region of Sardinia, } \\
\text { the State Property Agency }\end{array}$ & $\begin{array}{l}\text { Definition of procedures, methods, and timing of } \\
\text { disposal of the properties listed in the annexes }\end{array}$ \\
\hline $\begin{array}{l}21 \text { December } \\
2011\end{array}$ & $\begin{array}{c}\text { Resolution n. 45/5 Autonomous } \\
\text { Region of Sardinia }\end{array}$ & Integration to the 2008 Program Agreement \\
\hline $\begin{array}{l}18 \text { December } \\
2017\end{array}$ & $\begin{array}{l}\text { Memorandum of Understanding } \\
\text { between the Ministry of Defense and the } \\
\text { Autonomous Region of Sardinia }\end{array}$ & $\begin{array}{l}\text { Coordination of military activities present in the } \\
\text { territory of Sardinia with which in particular the } \\
\text { suspension of fire activities at the Sardinian Military } \\
\text { Proving Ground (MPG) is formalized from June } 1 \text { to } \\
\text { September } 30 \text { of each year }\end{array}$ \\
\hline
\end{tabular}

Finally, with the memorandum between the Ministry of Defense and the ARS dated 18 December 2017, the suspension of the exercises within the MPG from 1 June to 30 September was formalized in order to guarantee the exploitation and use of the coast, also consistent with the environmental defense policies deriving from the Natura 2000 Network and the regional landscape plan (PPR).

\subsection{Military Proving Ground (MPG) in Sardinia}

In Sardinia, the military bases were installed in 1956 with the construction of the three coastal military proving grounds: Capo Frasca, Teulada, and Salto di Quirra (Military Proving Ground Salto di Quirra, MPGSQ, case study, Section 2.3), with a total area of approximately $234 \mathrm{~km}^{2}$.

These MPGs together with the remaining military easements [23] account for about $1.5 \%$ of the total surface area of Sardinia, which in addition to blocking the air spaces during the exercises, determine that in some periods of the year almost the whole island is concerned as in Figure 3.

In particular, the MPG are intended for military services, such as training, experimentation with new weapon systems, simulated wars, deposits, etc. 

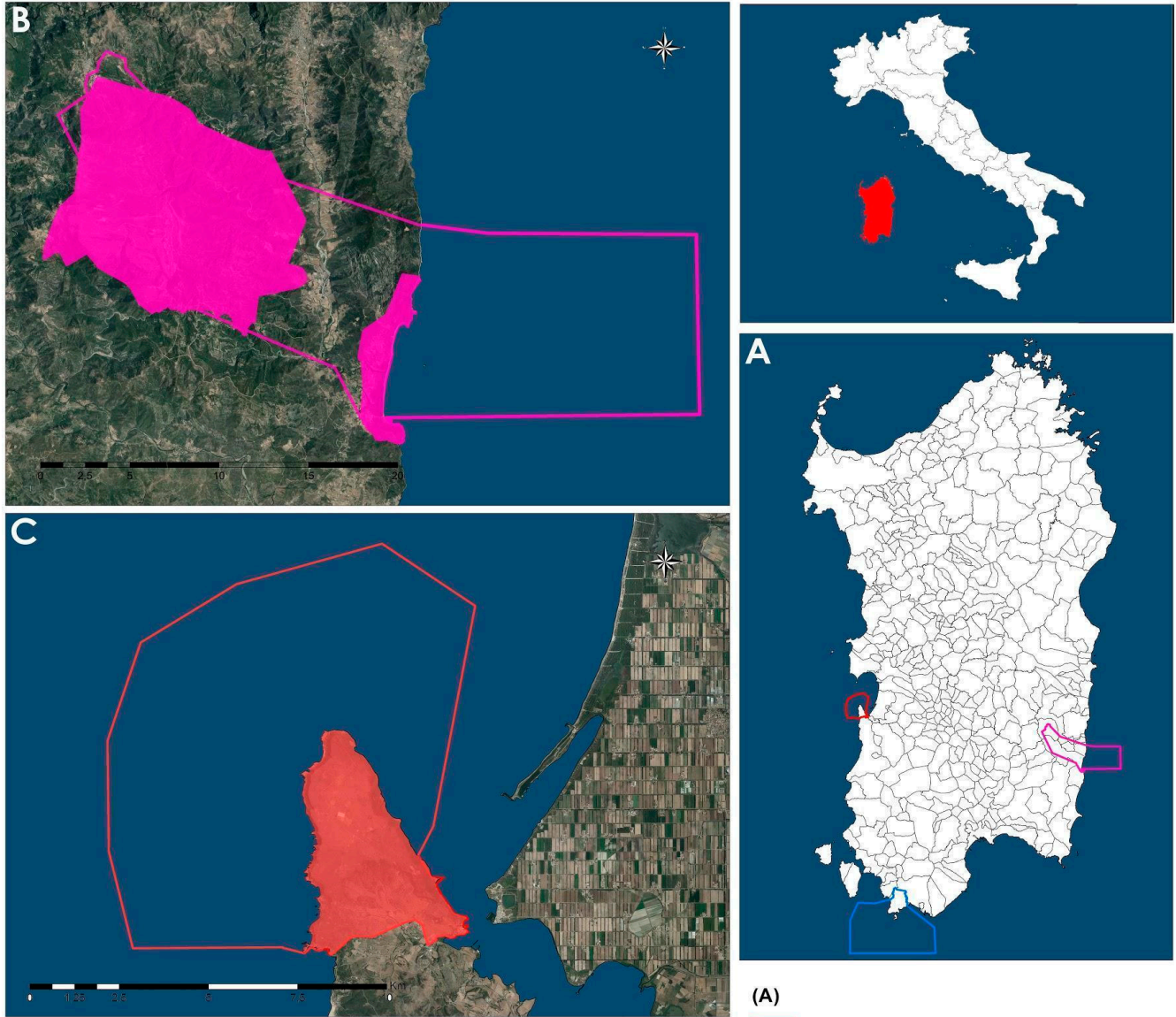

(A)
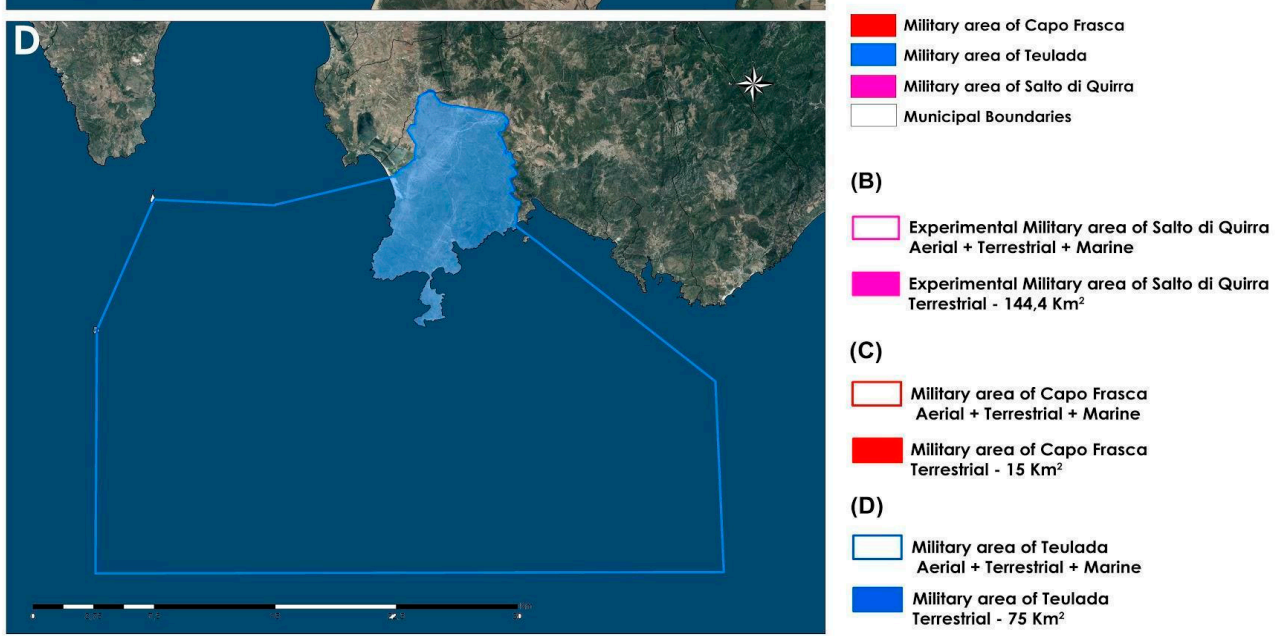

Figure 3. Maps of military training areas in the Sardinia region (Italy).

These services have always confirmed the strategic role of Sardinia in the context of the North Atlantic alliance of the political-military system related to control in the Mediterranean. These military services require a complex system of easement, with variable limitations, both in the inland and coastal areas and in the airspace. In particular, the limitations consist in the prohibition of the internal areas, in the permanent and/or temporary limitations in the coastal areas, and in the prohibition of flight in the air spaces. In this framework, the system of military services, which is expressed through the relative state property, land, sea, and air servitude, determines the complex and articulated system of military constraints that exist in Sardinia. Only in the last decade has the military state property been the object of specific state federalism, particularly in the coastal area, partly reducing military constraints. In fact, with the state-owned federalism process starting with Legislative Decree 85/2010, the transfer of part 
of the State's assets to the municipal administrations was envisaged. However, this process has not yet had the desired effects. In fact, in this situation, on the one hand, the ARS pushes for the non-onerous transfer of state property based on statutory regulations (while the decree provides for costs); on the other hand, the municipal administrations and local authorities are pushing for ownership to activate the development [24].

\subsection{The Case of Military Proving Ground of Villaputzu (MPGSQ)}

In this regional framework fits the case study of Murtas beach, in the Quirra coast, municipality of Villaputzu, an 'enclave' within the MPGSQ [25]. It represents the first case in Sardinia of planning for tourist use in the summer months and uses military in the remaining months of the year, the result of the complex process of state federalism (Sections 2.1 and 2.2). The MPGSQ is located in the southeastern part of Sardinia and develops mainly on two distinct areas: An area characterized by a plateau called Salto di Quirra [25]. The MPGSQ involves the municipalities of Villaputzu, Perdasdefogu, Tertenia, Ballao, Osini, Ulassai, Jerzu, and Arzana, as in Figure 4.

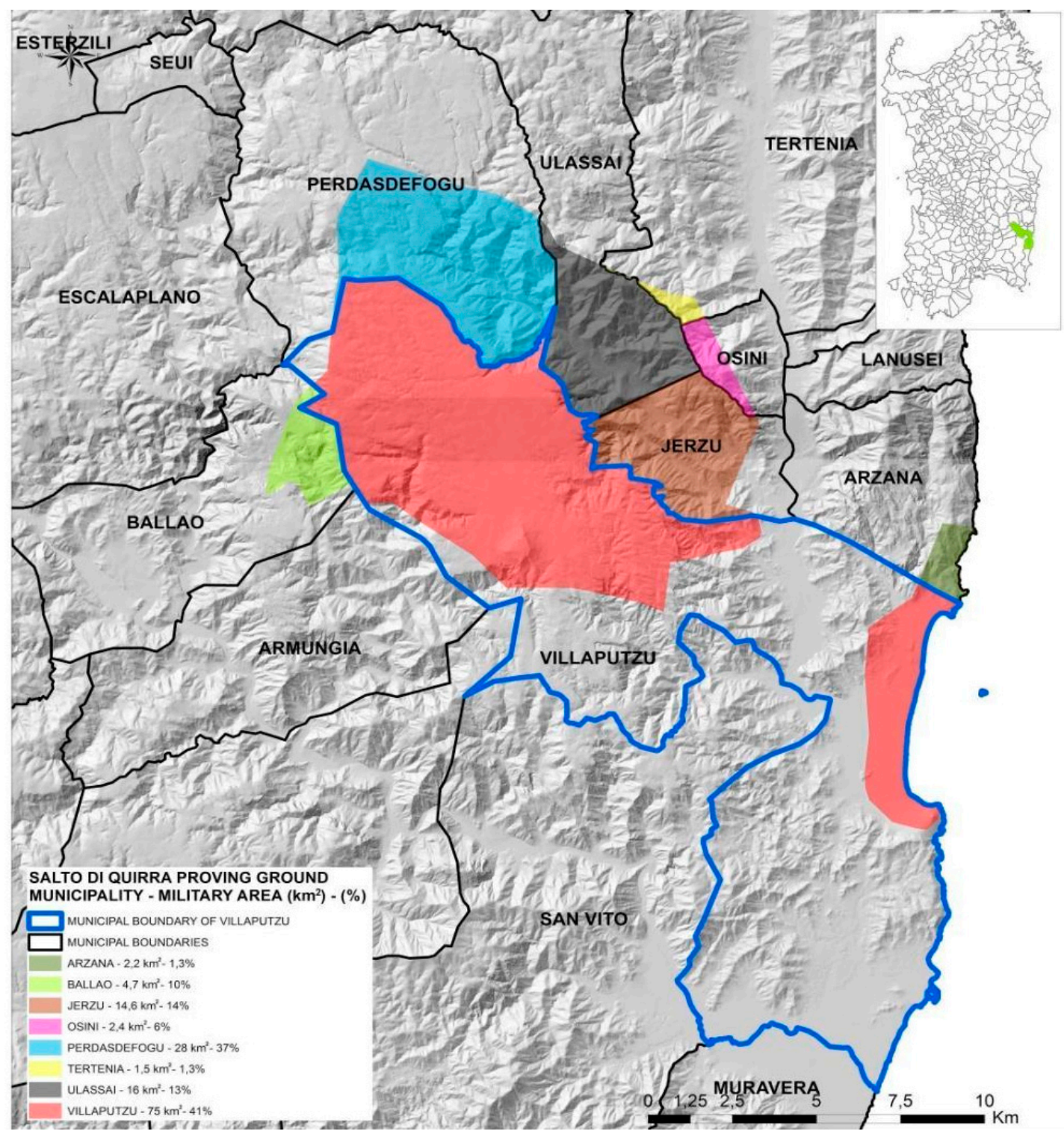

Figure 4. Municipalities affected by Military Proving Ground Salto di Quirra (MPGSQ). Percentage compared to the total municipal area. 
The municipality of Villaputzu covers about $181.25 \mathrm{~km}^{2}$ and is the most affected by the MPGSQ, with about $41 \%$ of the land area occupied by military easements. Furthermore, the MPGSQ at sea falls within a site of community interest (SCI) classified with code ITB040017 'Ponds of Murtas and S'Acqua Durci' [26] as in Figure 5.

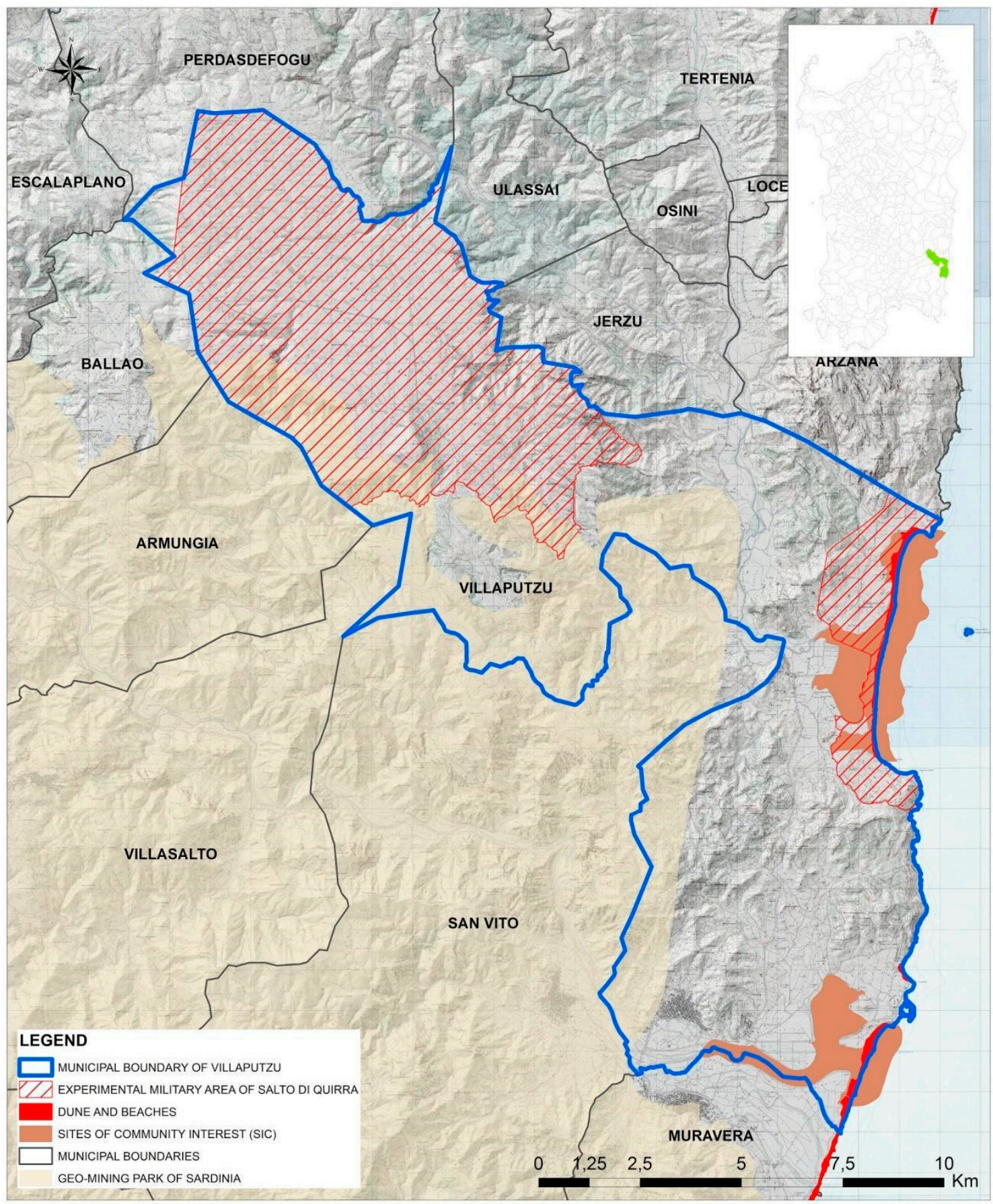

Figure 5. Military Proving Ground Salto di Quirra (MPGSQ) and the Site of Community Interest (SCI) of Villaputzu.

This situation deriving from military constraints has stimulated an impressive action from the bottom coming from the local community that has offered a sensitization of political opinion so that through the agreement of the Ministry of Defense and the municipality of Villaputzu of 27 June 2013, from June to September, tourist use on the beach of Murtas is allowed. 
In 2017, the beach of Murtas was then included in the regional list of bathing beaches, thus allowing the municipality of Villaputzu to include this beach within its local coastline plan (LCP).

\subsection{Planning and Management Tools for Coastal Uses}

The planning and management of the coastal environment requires careful assessment of both coastal evolutionary trends, such as marine and hydrodynamic weather phenomena, and the phenomena of increasing anthropic pressure connected to tourist use. This in order to integrate the planning and management of the coastal environment between risk mitigation and conscious use $[27,28]$. In this sense, the authors have identified the main instruments for the planning and coastal management of Villaputzu: The coastal use plan (LCP) and the SCI management plan (SCIMP) [29]. In particular, the need to equip coastal municipalities with the LCP stems from the need to regulate the use of maritime state-owned areas, such as beaches, for recreational tourism purposes in order to protect and enhance the coastal environmental heritage.

The Law of 4 December 1993 n. 494 (article 6 paragraph 3) gives the faculty to allow the regions to have plans for the use of state-owned maritime areas. Subsequently, with the Legislative Decree $112 / 98$, the delegation from the state to the regions was transferred for the functions related to 'the release of property concessions of the state of the inland navigation, of the maritime land and of areas of the territorial sea for purposes other than supplying of energy sources. This transfer of powers does not operate in ports and areas of national interest - SIN - identified by the decree of the President of the Council of Ministers of 21 December 1995. The Sardinia region-Regional Law of 12 June 2006, n. 9, the 'Assignment of functions to Local Authorities'-holds the task of adopting the general guidelines for the preparation of LCPs. Municipalities are assigned different functions on the subject of processing and approval of LCPs; concessions, on the assets of the maritime domain or inland navigation, for tourist recreation purposes, on uncovered areas, or those which involve easy removal facilities; and other administrative functions concerning maritime land ownership and the territorial sea not reserved for the region or the state.

The regulatory system where the LCP is inserted concerns the reorganization of maritime state property concessions.

According to the regional landscape plan (Regional Government Decree - DGR 36/7 of 2006), the municipalities are obliged, within the process of adaptation of the Municipal Urban Plans (MUPs) to the Regional Landscape Plan (RLP) [30], to draw up the LCP as an integral and substantial part of the municipal urban plan, and then the LR 8/2015 recognizes the LCP as an implementation plan. The general guidelines for the preparation of the LCP are currently represented by the 'guidelines' (Regional Council Resolution No. 10/5 dated 21 February 2017). In particular, the LCP regulates the use of the coasts and immediately contiguous territories for recreational tourism functions, dividing the coast in relation to the specific environmental characteristics, establishing the use and the related support services.

The LCPs in Sardinia often act within the territories of the Natura 2000 Network. Such a network represents the main instrument of the European Union policy regarding the conservation of biodiversity-established pursuant to Directive 92/43/CEE 'Habitat' and subsequent national transpositions-to guarantee the long-term maintenance of natural habitats and threatened flora and fauna species, divided into Sites of Community Interest (SCI), special protection areas (SPAs), and special areas of conservation (SAC). According to the recent literature, these are recognized as ecosystem services [31,32]. The LCP planning proposals must therefore take into account the SCI on which they act, so that the respective specific objectives are congruent.

\subsubsection{The Coastal Use Plan (LCP): Murtas Beach, Villaputzu}

In this framework, the Villaputzu LCP was developed, which, in addition to the state-owned maritime areas, also governs the contiguous areas, regulating road and pedestrian access to the areas 
in order to create an integration between the coast and the areas not immediately close to the coasts, thus also directing tourist flows towards less privileged areas as in Figure 6.

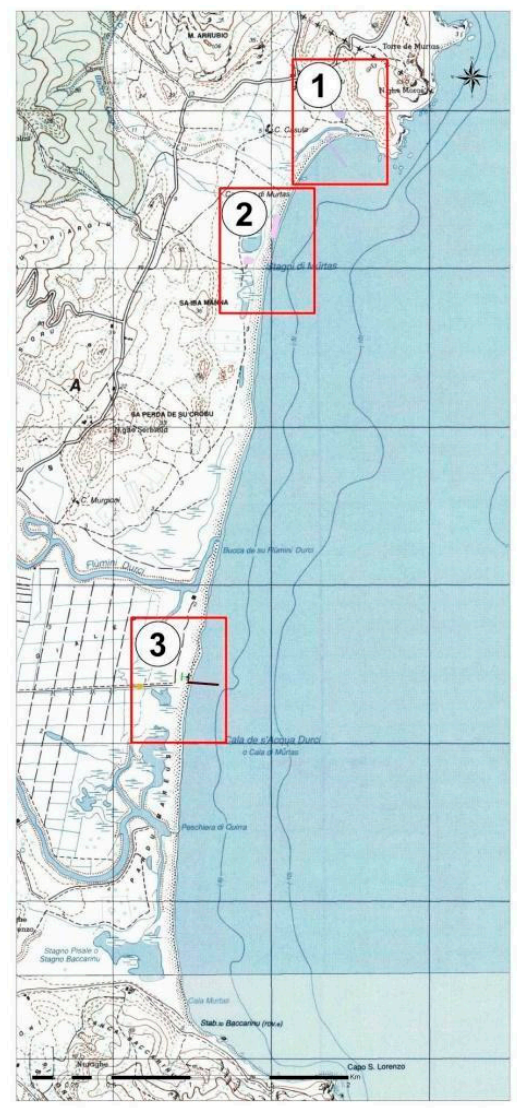

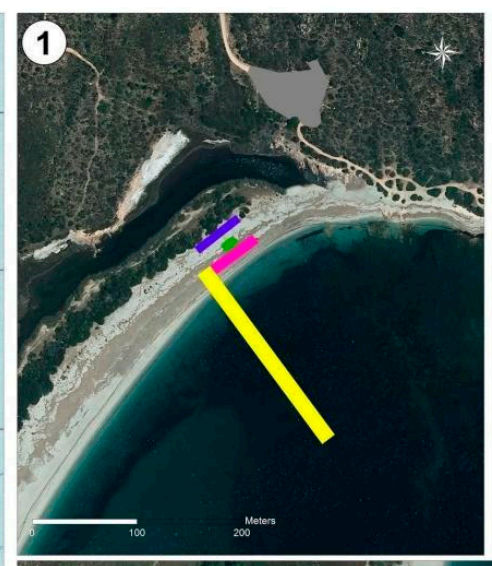

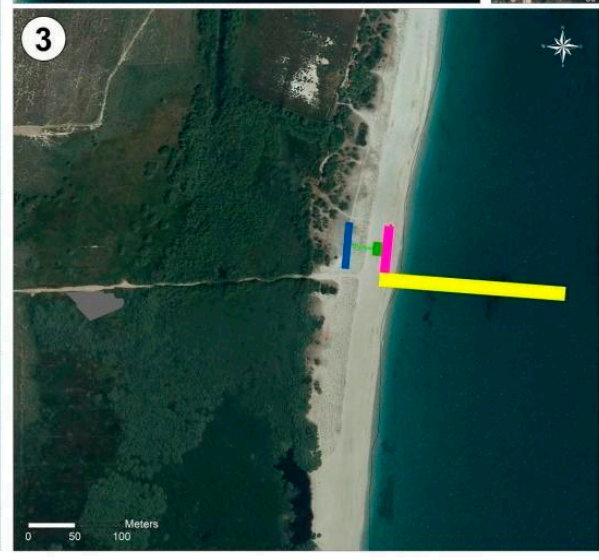

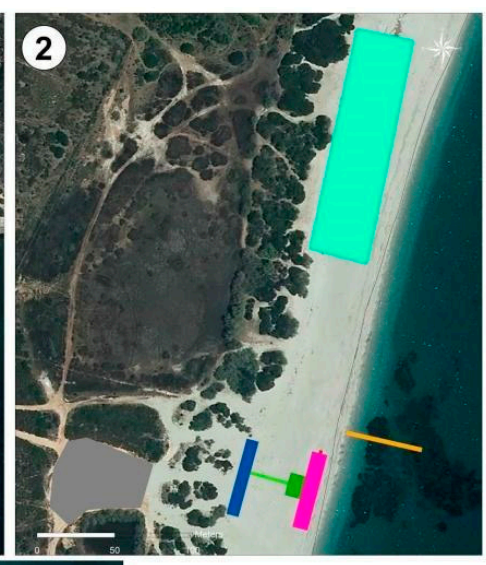

MURTAS BEACH Facilities - BAYWATCH TOWER BEACH SERVICES AND FIXED BEACH EQUUIPMENT
BEACHES SERVICES AND COMMERCIAL ACTIVITY AREA - PARKING AREA

FOOTBRIDGE
LAUNCHING CORRIDOR SENIOR PEOPLE AND SENIOR PEOPLE AND
DISABLED PEOPLE SERVICE AREA

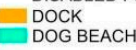

Figure 6. LCP concept Murtas beach, municipality of Villaputzu (2019).

In particular, the LCP proposes the following strategic objectives:

- Guarantee the conservation and protection of local coastal ecosystems, with particular reference to habitats-Directive 21 May 1992, 92/43/CEE and subsequent amendments;

- Harmonize actions on the territory for sustainable development, in particular by promoting measures for the reduction of degradation and land consumption processes;

- Promote and encourage environmental redevelopment through re-naturalization projects;

- Guarantee the continuity between the sand dunes and the ecological plant corridor, as well as improve the accessibility of the state-owned maritime areas;

- Promote innovation and diversification of the tourist offer; and

- Regulate the various activities for the purposes of integration and complementarity between them.

The Villaputzu LCP also affects the enclave of the MPG for the Salto di Quirra section (MPGSQ). This constitutes the first case in Sardinia of coastal planning that intends to reconcile the military activities of the winter period and the tourist ones recreating the summer period, in compliance with the current legislation in terms of health and safety and in the context of environmental monitoring [33].

\subsubsection{The Management Plan of the SCI Municipality of Villaputzu}

The SCI called 'Ponds of Murtas and S'Acqua Durci' (code ITB040017) located in the coastal sector of the mouth of the Rio Quirra, in central-eastern Sardinia, includes the portion of territory that from the promontory of Torre Murtas reaches Capo San Lorenzo, extending for an area of $7.4 \mathrm{~km}^{2}$, Figure 7 . 


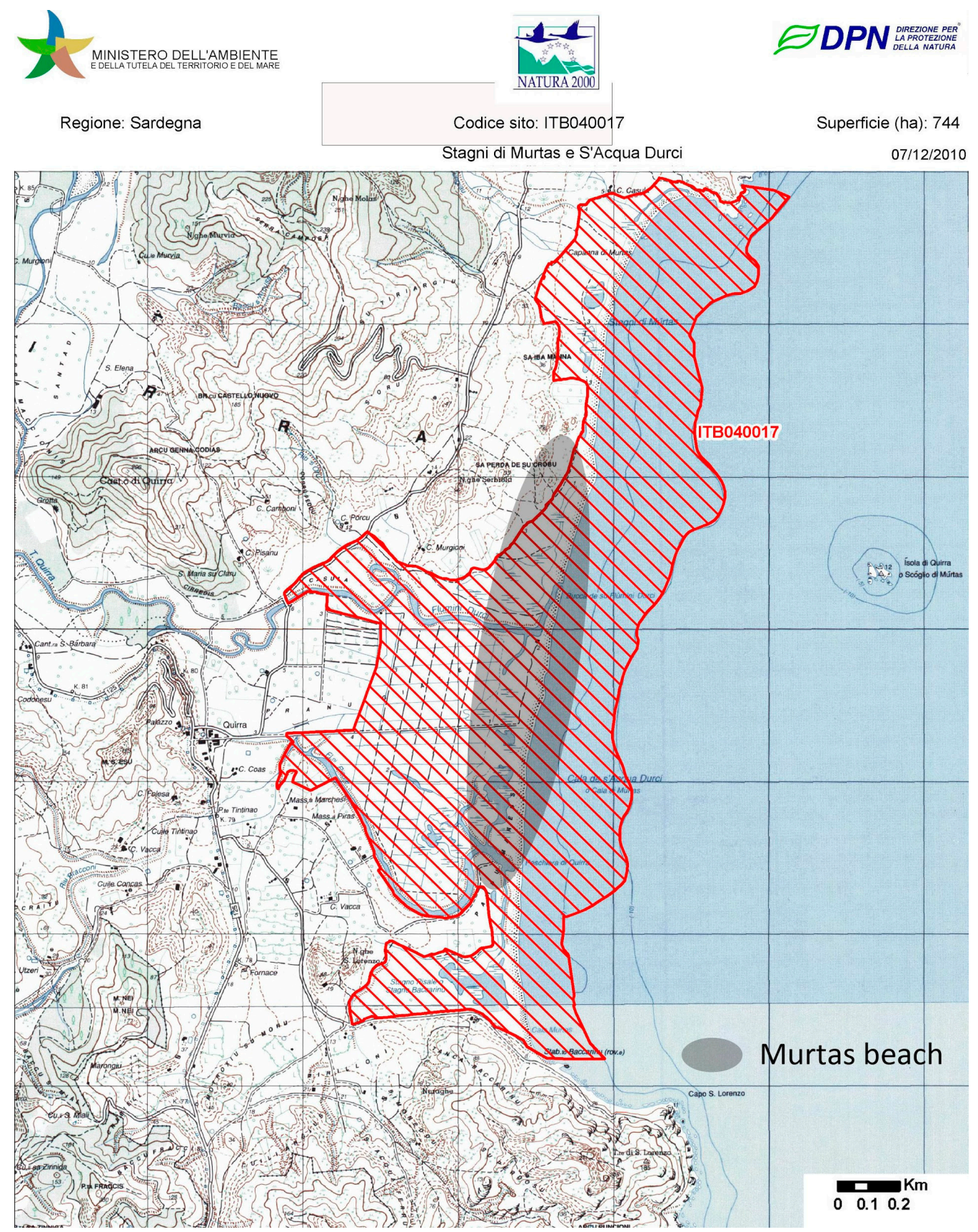

Figure 7. Sites of Community Interest (SCI) ITB040017 'Stagni di Murtas e S'Acqua Durci' (Source: https://www.minambiente.it/pagina/sic-zsc-e-zps-italia).

The management plan (SCIMP) regulates the SCI, which is consistent with the provisions of the art. 6 of the 'Habitat' Directive and of the art. 4 of Presidential Decree 120/2003, and has the objective of guaranteeing the conservation and protection of the habitats and species of fauna and flora, implementing protection and management strategies capable of allowing the maintenance of areas in optimal conditions, even in the presence of human activities, and thus favoring the maintenance of ecosystem services.

\subsubsection{Ecosystem Services, LCP (Murtas Beach), and Management Plan of the SCI of Villaputzu}

According to the definition given by the Millennium Ecosystem Assessment (2005), "the multiple benefits recorded by ecosystems for mankind" are expressed through four main categories: Life 
support, such as the nutrient cycle, soil formation, and primary production; procurement, such as the production of food, drinking water, and materials or fuel; regulation, such as climate and tide regulation, water purification, etc.; and cultural values, such as educational, recreational, etc.

In this sense, the importance of including ecosystem services in planning processes is supported by a vast literature. In fact, the overcoming of the sectoral approaches (Geneletti, 2011; Baker et al. 2013, Zoppi et al. 2018) [34-37], oriented to the coherence between the economic and environmental dimension (Danley et al. 2016) [37], build the prerequisites for the integration of ecosystem services within environmental planning. In particular, the transition to anticommons and semicommons is activated through the integrated environmental planning of ecosystem services. Therefore, to evaluate this integration referred to the case study, the methodology proposed by Mascarenhas et al. (2015) [38] was applied to the management plan of the SCI and to the Local Coastline Plan (LCP) of Murtas beach by searching for the following keywords, as in Table 2. Table one shows how the selection of the keywords related to the ecosystem services present in the LCP Murtas beach are highly representative in quantitative terms with respect to the management plan of SCI code ITB 040017. This confirms the role of the LCP strategy (Murtas beach) in the transition between anticommons and semicommons of the military proving ground of Villaputzu (MPGSQ).

Table 2. Number of keywords in Local Coastline Plan (LCP) Murtas beach (Villaputzu, Sardinia) and management plan of SCI (code ITB040017, Sardinia).

\begin{tabular}{ccc}
\hline Keywords & $\begin{array}{c}\text { LCP } \\
\text { Murtas Beach } \\
\text { Villaputzu }\end{array}$ & $\begin{array}{c}\text { Management Plan of SCI } \\
\text { Code ITB040017 }\end{array}$ \\
\hline ecosystemic | ecosystem & 3 & 2 \\
ecosystem service (s) & 2 & 2 \\
environmental service (s) & 2 & - \\
ecosystem balance & 2 & 3 \\
ecosystem functionality & 1 & - \\
ecosystem value & - & - \\
ecosystemic benefit (s) & 2 & - \\
regulating service (s) & 1 & - \\
Provisioning service (s) & 1 & - \\
cultural service (s) & - & - \\
Ecotourism & 2 & - \\
sustainable tourism & 1 & - \\
natural tourism | naturalistic & 2 & - \\
tourism & 2 & - \\
recreational service (s) & &
\end{tabular}

\subsubsection{Evaluation of the Congruence of Specific Objectives: LCP and SCIMP}

The authors then proceeded with the evaluation of the congruence of the specific LCP and SCIMP objectives, building the following logical framework, as in Table 3.

This congruence was evaluated both in qualitative terms in Figure 8 and in quantitative terms in Figure 9, as well as by examining the actions of the two instruments in Figure 10.

From the qualitative analysis in Figure 8, we can extrapolate an overall coherence between LCP and SCIMP, given by the prevalence of the congruence relations, in line with the assumptions of the integrated management of the coasts in Sardinia [39].

The authors subsequently built a matrix with the attribution of weights (quantitative evaluation) to the congruence relations to obtain the degree of convergence between the specific objectives of the LCP and SCIMP, Figure 9. 
Table 3. Logical framework: Specific Objectives of LCP and SCIMP.

\begin{tabular}{|c|c|}
\hline $\begin{array}{l}\text { Specific Objectives [SO] of Local Coastal } \\
\text { Plan [LCP] }\end{array}$ & $\begin{array}{l}\text { Specific Objectives [SOs] of Sites of Community } \\
\text { Importance-Management Plan [SCIMP] }\end{array}$ \\
\hline $\begin{array}{c}\text { LCP_SO_01-Promoting innovation and } \\
\text { diversification of the tourism offer, also through an } \\
\text { integrated advertising-offer circuit }\end{array}$ & $\begin{array}{c}\text { SCIMP_SO_01-Improve the quality and } \\
\text { effectiveness of the organization responsible for the } \\
\text { implementation, verification and updating of the } \\
\text { Management Plan. }\end{array}$ \\
\hline $\begin{array}{l}\text { LCP_SO_02_Establish a framework for the } \\
\text { harmonization of the actions of public and private } \\
\text { subjects on the coastal strip. }\end{array}$ & $\begin{array}{c}\text { SCIMP_SO_02-Improve the quality and } \\
\text { effectiveness of communication and territorial } \\
\text { control activities. }\end{array}$ \\
\hline $\begin{array}{l}\text { LCP_SO_03_Promote and encourage environmental } \\
\text { redevelopment of the areas identified in the PUL }\end{array}$ & $\begin{array}{l}\text { SCIMP_OS3 - Improve the quality and effectiveness } \\
\text { of monitoring activities }\end{array}$ \\
\hline $\begin{array}{l}\text { LCP_SO_04-Adopt recognition and monitoring } \\
\text { systems of the coastlines in order to activate actions } \\
\text { aimed at reducing the degradation and consumption } \\
\text { processes of the territory. }\end{array}$ & $\begin{array}{l}\text { SCIMP_SO_04-Restore and promote the expansion } \\
\text { of all the surfaces that can be potentially occupied by } \\
\text { habitats and habitats of species thanks to the } \\
\text { involvement of stakeholders. }\end{array}$ \\
\hline $\begin{array}{l}\text { LCP_SO_05_Promote the decongestion of some } \\
\text { stretches of coastline where the greatest load of } \\
\text { bathing users is usually concentrated. }\end{array}$ & $\begin{array}{l}\text { SCIMP_SO_05-Removal of landfills, exotic and } \\
\text { invasive species and stray dogs. }\end{array}$ \\
\hline $\begin{array}{c}\text { LCP_SO_06-To guarantee the conservation and } \\
\text { protection of local coastal ecosystems in harmony } \\
\text { with the development of tourist activities and the free } \\
\text { use of stretches of coast. }\end{array}$ & $\begin{array}{c}\text { SCIMP_SO_06-Implementation of internal nature } \\
\text { trails, adaptation of parking areas, and ecological } \\
\text { connection of the SCI with the other neighboring SCIs } \\
\text { and SPAs. }\end{array}$ \\
\hline $\begin{array}{l}\text { LCP_SO_07-To guarantee the continuity between } \\
\text { the sandy shore and the dune system, improving the } \\
\text { accessibility of the state-owned maritime areas }\end{array}$ & \\
\hline
\end{tabular}

\begin{tabular}{|c|c|c|c|c|c|c|}
\hline & SCIMP_SO_01 & SCIMP_SO_02 & SCIMP_SO_03 & SCIMP_SO_04 & SCIMP_SO_05 & SCIMP_SO_06 \\
\hline LCP_SO_01 & $\checkmark$ & $\checkmark$ & $\checkmark$ & $\checkmark$ & $x$ & $\checkmark$ \\
\hline LCP_SO_02 & $\checkmark$ & $\checkmark$ & $\checkmark$ & $x$ & $\checkmark$ & $\checkmark$ \\
\hline LCP_SO_03 & $\checkmark$ & $\checkmark$ & $\checkmark$ & $\checkmark$ & $\checkmark$ & $\checkmark$ \\
\hline LCP_SO_04 & $x$ & $\checkmark$ & $\checkmark$ & $\checkmark$ & $\checkmark$ & $\checkmark$ \\
\hline LCP_SO_05 & $x$ & $\checkmark$ & $\checkmark$ & $\checkmark$ & $\checkmark$ & $\checkmark$ \\
\hline LCP_SO_06 & $\checkmark$ & $\checkmark$ & $\checkmark$ & $\checkmark$ & $\checkmark$ & $\checkmark$ \\
\hline LCP_SO_07 & $x$ & $\checkmark$ & $\checkmark$ & $\checkmark$ & $\checkmark$ & $\checkmark$ \\
\hline
\end{tabular}

Figure 8. Qualitative assessment of the specific objectives of LCP and SCIMP.

From Figure 9, it can be extrapolated that there is a maximum convergence for about $88 \%$ of cases, a weak convergence in $23.8 \%$ of cases, and no convergence in $11.9 \%$ of cases.

The authors also proceeded to assess the adequacy of the individual actions envisaged by the LCP and the ICS management plan to achieve their specific objectives.

The results of the consistency assessment of the actions (LCP and SCI) are shown in Figure 8. The white squares indicate that there are no interferences between the actions of the two instruments, the + symbol indicates a positive congruence between the actions, and the ++ symbol indicates highly positive congruence between actions. 


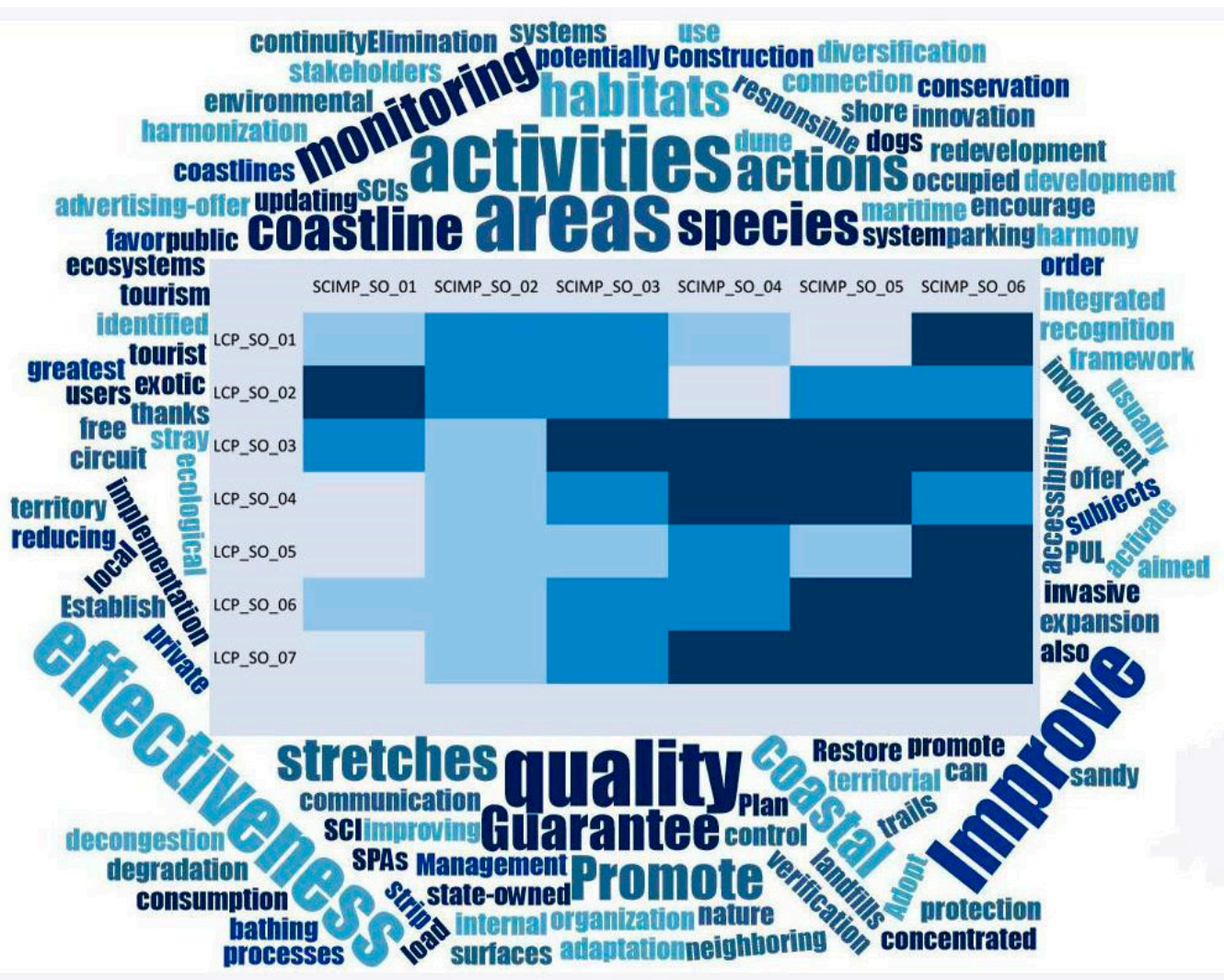

0 no convergence 0.25 weak convergence $\quad 0.5$ medium convergence 1 strong convergence

Figure 9. Convergence matrix (qualitative evaluation) of the objectives of the PUL and the SCIMP.

\begin{tabular}{|c|c|c|c|c|c|c|c|c|c|c|c|c|c|c|c|c|c|c|c|c|c|c|c|c|c|c|c|c|}
\hline \multirow{2}{*}{$\begin{array}{c}\text { ICP } \\
\text { ACTIONS }\end{array}$} & \multicolumn{28}{|c|}{ SCIMP ACTIONS } \\
\hline & Al1 & $\mathrm{Al} 2$ & $A \mid 3$ & Al4 & A15 & A16 & A17 & Al8 & A19 & Al10 & Al11 & A112 & \begin{tabular}{|l|l|l|l|} 
Al13 \\
\end{tabular} & Al14 & Al15 & RE1 & IN1 & IN2 & MR1 & MR2 & MR3 & MR4 & MR5 & \begin{tabular}{|l|l|} 
MR6 \\
\end{tabular} & MR7 & EP1 & EP2 & EP3 \\
\hline LCP_Act_01 & + & & & + & & & & & & & & & & & & & & & & & & & & & & & & \\
\hline LCP_Act.02 & & ++ & & & & & & & & & & & & & & & & & & & & & & & & & & \\
\hline LCP_Act.03 & & & & & & & & & & & & & ++ & & & & & & & & & & & & & & & \\
\hline LCP_Act.04 & & & + & & & & & & & + & & & & & & + & & & & & & & & & & & & \\
\hline LCP_Act.05 & & & & & & & & & & & & & & & & & & & & & & & & & & & & \\
\hline LCP_Act.06 & & & + & & & & + & + & + & & t+ & & & t+ & & + & & & & & & & & & & & & \\
\hline LCP_Act.07 & & & & & & & & & & & & & & & & & & & & & & & & & & & & \\
\hline LCP_Act.08 & & & & & & & & & & & & + & & & & & & & + & + & + & & & & + & & & \\
\hline LCP_Act.09 & & & & & & & & & & & & + & & & + & + & + & & & & & & & & & & & \\
\hline LCP_Act.10 & & & & & & & & & & & & & & & & 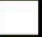 & & & & & & & & & & $\begin{array}{l}+ \\
+\end{array}$ & ++ & \\
\hline LCP_Act.11 & & & ++ & & & & & & + & ++ & & & & & & + & & & & & & & & & & & & \\
\hline Al1- $15=A C$ & & & ver & & & & & & & & IN1-2 & & entives & & $\bar{M}$ & & Moni & itc & $\mathrm{gpr}_{\mathrm{pr}}$ & rams & & & & & & rog & & \\
\hline
\end{tabular}

Figure 10. Evaluation of the congruence between the actions of LCP and SCIMP.

Figure 10 shows that there are no negative interferences between the actions of the respective plans, therefore the pursuit of objectives that have a low degree of convergence or no convergence does not derive from an interference between actions, but from actions that act on levels and different themes without conflict.

\section{Results and Discussion}

The proposed approach highlights how an integrated environmental planning of ecosystem services can allow the transition from anticommons to semicommons, where multiple interests coexist. This transition is in fact a fundamental phase, often neglected in environmental planning, but which 
requires the utmost attention during changes in the use of the territory and in particular in the occasion of the disposal of public assets. This transition is favored by the LCP, local coast planning, in coherence with the environmental protection policies (SCIMP) and the military regulations.

In particular, in the specific case study of the Villaputzu municipality, Quirra beach, the coexistence of multiple military, public, and private interests found a synthesis in the LCP. In fact, the authors realized a specific grid of converging specific objectives that can converge, particularly in terms of the overall convergence of the specific objectives of the Villaputzu LCP with the agreements and protocols of understanding between the Ministry of Defense and the Sardinia region (Table 1), and with the specific objectives of the SCIMP. An attempt was made here to respond to the debate of the local communities that they oppose military servitude, especially in the coastal area. Furthermore, this methodological application referred to the military enclave of Villaputzu and can be replicated in the remaining contexts of Sardinia subjected to military servitude, as reported in Figure 1, and more generally in the occasion of a transition of public goods from anticommons to semicommons. In this paper, we tackled a little covered issue, that of allowing the co-existence of military zones with civil uses, and particularly those related to leisure and tourism, by the application of a spatial planning policy instrument-the LCP - as the framework in which the different interests on a specific territory were considered together. The example cited and analyzed is not a trivial one and implied profound reflections on the concept, planning aspects, and opportunities deriving from a concurrent use of areas presenting military bonds and tourism.

With reference to the concept, it is worth noting that considerations have been made on the nature of the goods as semicommons, as those particular goods holding all the private collective goods, but at the same time attributing a set of public rights to other subjects, as those deriving from being territories subject to easements for military purposes. Such a concept seems nearly straightforward and obvious; nonetheless, it is not explicitly cited when considering this kind of use.

When moving to planning, the consideration of the delimitation of the areas is central, and from a visual and graphical (and cartographical) point of view, the precise localization of the areas, which are the bonds in terms of both military and environmental uses, as well as the possible destinations to a civil use, are important. That point alone required a deep and articulated survey on the planning instruments as well as on the official documents and materials to correctly identify the areas and different aims, bonds, and opportunities on a given territory.

A last, innovative, and interesting point deals with the evaluation process, which aimed at developing new techniques for resolving issues in terms of bonds, and proposing common and concurrent planning capable of complying with most of the different aims and orientations of the planning issues of origin. In the case study tackled here, the authors, as scholars and professionals involved in studying spatial planning issues, as well as working with local authorities on spatial planning issues, proposed an instrument as an evaluation matrix for putting together the different pieces of evaluation elements belonging to the different levels of planning, as military purposes, local spatial and urban planning, and environmental constraints.

Among the benefits expected by the novel approach presented here, there is that of allowing a wider awareness and acceptance of bond and easements over environmentally sensitive and protected areas, as well as a fair exploitation of resources.

\section{Conclusions}

The methodology proposed by the authors, consisting in the evaluation of congruence and convergence between the specific objectives of LCP and SCIMP and in the evaluation of congruence of the respective actions, allowed us to demonstrate how a military enclave, such as that highlighted in the case study of Villaputzu (Sardinia, Italy), can be configured as a semicommon [40], which is able to configure services' ecosystems $[36,41]$ and use.

The transition from anticommon to common of the Villaputzu military enclave was in fact possible due to ecosystem services. In particular, the condition of a semicommon good incorporates the 
private sector related to tourism and beach services. In the presence of this regime (semicommons) the following two effects arise, deriving from the combined use: 1. Economies of scale are obtained thanks to the combination of public interests (military activities) and private (services seasonal tourist); 2. environmental protection: The interaction between private use (coastal use plan (LCP) and the common (management plan of the SCI of Villaputzu) reduces the phenomenon of excessive use. In this sense, ecosystem services offered in the LCP, Murtas beach allow responsible use based on the dynamism of the natural context. In fact, the military enclave has led to an anticommons, but it is also true that it has preserved the coast, prohibiting the fruition. This prohibition allowed the natural beach to evolve without human interference in the Murtas beach. In this sense, the LCP is inserted and proposes tourist use compatible with conservation and valorization of the natural heritage. It should be noted, however, that the research carried out appears to be at an initial stage, and with little evidence of other cases in sensible areas around the world. To the authors' knowledge, no other cases have been widely tackled in the literature and in spatial planning actions. The authors in particular highlighted, in theory and practice, how a concurrent approach on planning can be adopted, allowing de facto multiple targets to be addressed: Military operations, environmental protection and management, and tourist recreational use. The basic idea, extended for the consideration of the goods and services considered as 'semicommons', is that their use, observed by means of a fit-for-purpose matrix, can be in some sense concurrent. If rights of use can be present on a theory, it is extremely unlikely that the same territory is subjected to different uses at the same time, or at least this can be regulated and planned. A right of use should not translate into a perpetual use of a given portion of territory, as that can be in some particular moments of the year and/or of the day. This is valid for proving grounds-generally used in certain circumstances and moments-as well as tourism, which is generally subject to strong levels of seasonality in the presence of tourists and in the use of areas. Appropriate and calibrated planning can act also in terms of urgency or special cases in which a dominant use can overcome the other ones but adopting adequate announcements and communication.

The study developed here it is also interesting because it can be replicated in other similar contexts and where concurrent planning for sustainable use is also necessary in the territories used for military defense. In changing times in which military needs change the ways in which operations and training are performed, a convergence, at least in periods of time and for a certain amount of space, is actually needed. Some Italian regions, and Sardinia in particular, present a vast heritage of military grounds and easements, the offspring of the Cold War period, which are now still persisting. However, while the military presence has reduced its size and operating methods, in terms of personnel and resources, it did not reduce the occupied spaces and easement. In such sense, the authors have proposed an approach that takes into account the change, in the interests of both military and civilian uses. In this sense, little research seems to have tackled such an issue. Further research will be carried out in the same region and in other ones, where the heritage of military forces is still strong and pushes for a reuse are ongoing, with little delayed responses. The authors therefore intend to continue the research by evaluating the performance of ecosystem services on the occasion of semicommons connected to military proving grounds (MPGs).

Author Contributions: The paper derives from the join reflections of authors. However, Section 1 can be attributed to G.B. (Ginevra Balletto) and L.M.; Sections 2 and 2.1, Sections 2.2 and 2.3 to G.B. (Ginevra Balletto) and A.M.; Sections 2.4, 2.4.1 and 2.4.2 to G.B. (Ginevra Balletto), A.M. and N.F.; Sections 2.4.3 and 2.4.4 to G.B. (Ginevra Balletto); Abstract and Section 3 to G.B. (Giuseppe Borruso); Section 4 can be attributed to G.B. (Ginevra Balletto). All authors have read and agreed to the published version of the manuscript.

Funding: This research received no external funding.

Conflicts of Interest: The authors declare no conflict of interest. 


\section{Glossary}

LCP Local coastline plan: Municipal plan that defines the structure of the coastlines through an integrated and systemic management that allows a guarantee of the preservation and enhancement of the integrity of the state property for tourist uses.

SCI Site management plan of community interest: It is the management tool for specific measures, required by the 'Habitat' directive 92/43/EEC, for the conservation of natural habitats and species of wild flora and fauna of community interest, taking into account the particularities of the specific site.

MPG Military proving ground: The training area is a military installation or reservation where weapons or other military technology are experimented with or are tested, or where military tactics are tested. Military area: A facility that houses military equipment and personnel.

\section{References}

1. Angiolini, C.S.A. La Questione Dei Beni Comuni: Un Itinerario FRA Regimi Dei Beni E Diritti Fondamentali. Ph.D. Thesis, Università Ca' Foscari, Venezia, Italy, 2018.

2. Imperiale, F. Il Valore Dei Beni Culturali Nel Patrimonio Dello Stato Italiano; FrancoAngeli: Milano, Italy, 2018.

3. Caruso, R. Chiamata Alle ARMI: I Veri Costi Della Spesa Militare in Italia; EGEA spa: Burago di Molgora, Italy, 2018.

4. Hardin, G. The Tragedy of the Commons. Science 1968, 162, 1243-1248. [PubMed]

5. Marciano, A.; Frischmann, B.M.; Ramello, G.B. Tragedy of the Commons after 50 Years. 2019, 3451688. Available online: https://ssrn.com/abstract=3451688 (accessed on 15 May 2019).

6. Heller, M.A. The Tragedy of the Anticommons: Property in the Transition from Marx to Markets. Harv. Law Rev. 1997, 111, 621-688. [CrossRef]

7. Heller, M.A.; Eisenberg, R.S. Can Patents Deter Innovation? The Anticommons in Biomedical Research. Science 1998, 280, 698-701. [CrossRef] [PubMed]

8. Gastaldi, F.; Camerin, F. Processi di dismissione degli immobili militari. Temi e problemi aperti per la rigenerazione urbana in Italia. Sci. Reg. 2017, 16, 103-120.

9. Odoni, M. Degrado ambientale prodotto da esercitazioni militari tra interessi individuali e sicurezza nazionale alla luce del principio di non discriminazione. Diritti Um. E Dirit. Internazionale 2018, 2, 269-306.

10. Esu, A.; Maddanu, S. Military pollution in no war zone: The military representation in the local media. Journalism 2018, 19, 420-438. [CrossRef]

11. Hreško, J.; Petrovič, F.; Mišovičová, R. Mountain landscape archetypes of the Western Carpathians (Slovakia). Biodivers. Conserv. 2015, 24, 3269-3283. [CrossRef]

12. Špulerová, J.; Dobrovodská, M.; Izakovičová, Z.; Kenderessy, P.; Petrvič, F.; Štefunková, D. Developing a strategy for the protection of traditional cultural landscapes based on a complex landscape-ecological evaluation (the case of a mountain land scape in Slovakia). Morav. Geogr. 2013, 21, 15-26. [CrossRef]

13. Zentelis, R.; Lindenmayer, D. Bombing for Biodiversity-Enhancing Conservation Values of Military Training Areas. Conserv. Lett. 2015, 8, 299-305. [CrossRef]

14. Silva Arimoro, O.A.; Reis Lacerda, A.C.; Tomas, W.M.; Astete, S.; Roig, H.L.; Marinho-Filho, J. Artillery for Conservation: The Case of the Mammals Protected by the Formosa Military Training Area, Brazil. Trop. Conserv. Sci. 2017, 10. [CrossRef]

15. Ellwanger, G.; Müller, C.; Ssymank, A.; Vischer-Leopold, M.; Paulsch, C. Management of Natura 2000 Sites on Military Training Areas; Landwirtschaftsverlag: Münster, Germany, 2016; p. 152.

16. Reinhardt, I.; Kluth, G.; Nowak, C.; Szentiks, C.A.; Krone, O.; Ansorge, H.; Mueller, T. Military training areas facilitate the recolonization of wolves in Germany. Conserv. Lett. 2019, 12, e12635. [CrossRef]

17. Jenni, G.D.L.; Peterson, M.N.; Cubbage, F.W.; Jameson, J.K. Assessing biodiversity conservation conflict on military installations. Biol. Conserv. 2012, 153, 127-133. [CrossRef] 
18. Paloyo, A.R.; Vance, C.; Vorell, M. The regional economic effects of military base realignments and closures in germany. Def. Peace Econ. 2010, 21, 567-579. [CrossRef]

19. Camerin, F.; Gastaldi, F. II Ruolo dei Fondi di Investimento Immobiliare Nella Riconversione del Patrimonio Immobiliare Pubblico in Italia. Working papers. Rivista online di Urban@it2018, 2/2018. Available online: https://www.urbanit.it/wp-content/uploads/2018/10/BP_Camerin_Gastaldi-002.pdf (accessed on 15 May 2019).

20. Ellwanger, G.; Reiter, K. Nature conservation on decommissioned military training areas-German approaches and experiences. J. Nat. Conserv. 2019, 49, 1-8. [CrossRef]

21. Smith, H.E. Semicommon property rights and scattering in the open fields. J. Leg. Stud. 2000, 29, 131-169. [CrossRef]

22. Bertacchini, E.; De Mot, J.P.B.; Depoorter, B. Never two without three: Commons, anticommons and semicommons. Rev. Law Econ. 2009, 5, 163-176. [CrossRef]

23. Perelli, C. Geografie militari e nuovi movimenti di opposizione alle basi in Sardegna. In Proceedings of the International Conference Military Landscapes. A future for Military Heritage, La Maddalena, Italy, 21-24 June 2017; Skira: Milan, Italy, 2017; pp. 1210-1217.

24. Colavitti, A.M.; Serra, S.; Usai, A. Demanio Militare e "Beni Comuni": regolazione dei rapporti interistituzionali e coinvolgimento della società civile nei processi di valorizzazione della Regione Sardegna. In Commons/Comune: Geografie, Luoghi, Spazi, Città., Giornata di Studio Della Società di Studi Geografici Rome, Italy, 11 dicembre 2015 2016; Società di Studi Geografici: Firenze, Italy, 2016; pp. 613-620.

25. Codonesu, F. Servitù Militari Modello di Sviluppo e Sovranità in Sardegna; CUEC Editrice: Cagliari, Italy, 2013; Volume 23.

26. SardegnaAmbiente Web Site. Available online: http://www.sardegnaambiente.it/documenti/18_183_ 20140507151419.pdf (accessed on 15 May 2019).

27. Marx, J.T.; Liebenberg, I. Into the future: Donkergat Military Training Area and the Langebaan Ramsar site. J. Transdiscipl. Res. S. Afr. 2019, 15, 1-11. [CrossRef]

28. Seidel, V.; Dourte, D.; Diamond, C. Applying Spatial Mapping of Remotely Sensed Data to Valuation of Coastal Ecosystem Services in the Gulf of Mexico. Water 2019, 11, 1179. [CrossRef]

29. Leone, F.; Zoppi, C. Local Development and Protection of Nature in Coastal Zones: A Planning Study for the Sulcis Area (Sardinia, Italy). Sustainability 2019, 11, 5095. [CrossRef]

30. Sardegna Territorio Web Site. Available online: http:/www.sardegnaterritorio.it/paesaggio/ pianopaesaggistico2006.html (accessed on 15 May 2019).

31. Ministero dell'Ambiente e Della Tutela del Territorio e del Mare Web Site. Available online: https: //www.minambiente.it/pagina/rete-natura-2000 (accessed on 15 May 2019).

32. Santolini, R.; Morri, E.; Scolozzi, R. I servizi ecosistemici nelle aree protette e oltre i loro confini. Urban. Inf. 2015, 263, 41-43.

33. Regione Sardegna Web Site. Available online: http://82.85.20.38/profili/stazione/profilo/id/665 (accessed on 15 May 2019).

34. Geneletti, D. Assessing the impact of alternative land-use zoning policies on future ecosystem services. Environ. Impact Assess. Rev. 2013, 40, 25-35. [CrossRef]

35. Blouin, M.; Hodson, M.E.; Delgado, E.A.; Baker, G.; Brussaard, L.; Butt, K.R.; Cluzeau, D. A review of earthworm impact on soil function and ecosystem services. Eur. J. Soil Sci. 2013, 64, 161-182. [CrossRef]

36. Lai, S.; Leone, F.; Zoppi, C. Strategic environmental assessment and enhancement of ecosystem services: a study concerning spatial planning in Sardinia (Italy). Curr. Politics Econ. Eur. 2018, 29, 393-412.

37. Danley, B.; Widmark, C. Evaluating conceptual definitions of ecosystem services and their implications. Ecol. Econ. 2016, 126, 132-138. [CrossRef]

38. Mascarenhas, A.; Ramos, T.B.; Haase, D.; Santos, R. Ecosystem services in spatial planning and strategic environmental assessment-A European and Portuguese profile. Land Use Policy 2015, 48, 158-169. [CrossRef]

39. Lai, S.; Leone, F. La pianificazione nei paesaggi costieri: l'applicazione del concetto di integrazione nelle esperienze di due aree protette italiane. In Proceedings of the Seventh International Symposium Monitoring of Mediterranean Coastal Areas: Problems and Measurement Techniques, Livorno, Italy, 19-21 June 2018; Benincasa, F., Ed.; Firenze University Press: Firenze, Italy, 2018. 
40. Ling, G.H.T.; Ho, C.S.; Tsau, K.Y.; Cheng, C.T. Interrelationships between Public Open Space, Common Pool Resources, Publicness Levels and Commons Dilemmas: A Different Perspective in Urban Planning. Int. J. Built Environ. Sustain. 2019, 6, 13-21. [CrossRef]

41. Cannas, I.; Lai, S.; Leone, F.; Zoppi, C. Green infrastructure and ecological corridors: A regional study concerning Sardinia. Sustainability 2018, 10, 1265. [CrossRef]

(C) 2020 by the authors. Licensee MDPI, Basel, Switzerland. This article is an open access article distributed under the terms and conditions of the Creative Commons Attribution (CC BY) license (http://creativecommons.org/licenses/by/4.0/). 